СУЧАСНИЙ СТАН
ТА ОСОБЛИВОСТІ
ФОРМУВАННЯ
СОЦАЛЬНИХ
СТАНДАРТІВ В
УКРАӤНІ

СУЧАСНИЙ СТАН ФОРМУВАННЯ

СТАНДАРТІВ В УКРАÏHI

\author{
БЕРЕЗНК С.В., \\ кандидат економічних наук, доцент \\ кафедри адміністративного менеджсменту \\ та альтернативних джерел енергї, \\ Вінницький національний аграрний університет
} (м. Вінниця)

У статті розглянуто сутність економічної категорії «продовольча безпека», визначено й охарактеризовано ї̈ складові, здійснено оцінку стану продовольчої безпеки України й означено основні фактори, які впливають на неї.

Розглянуто норми споживчого кошика украӥния у продуктовій частині й фактичне споживання продуктів харчування, а також встановлено, щуо вони не відповідають науковообтрунтованим рекомендаціям Міністерства охорони здоров'я України щзодо повноцінного харчування. Аналіз середньорічного споживання основних продуктів харчування свідчить про те, що протягом 2000-2020 рр. украйниі почали споживати більше продуктів харчування, тобто загалом стали харчуватися краще, проте їхній рачіон є неоптимальним. 3'ясовано, шзо під час визначення продуктової частини вітчизняного споживчого кошика використовується методика, яка була розроблена понад 30 років тому, $і$ яка не враховує наявних нових $i$ сучасних груп товарів, тому, відповідно, потребує удосконалення 3 урахуванням передового світового досвіду.

Встановлено, щзо вартість набору споживчого кошика визначається прожитковим мінімумом, який також лежить в основі визначення розміру пенсій та мінімальної заробітної плати.

Досліджено рівень бідності в Украӥні й визначено, щзо низькі доходи громадян не дають можливість їм повноцінно харчуватися, щзо впливає на структуру спожитих продуктів харчування. Як наслідок, частка витрат на продукти харчування у сукупних витратах домогосподарств україниів є досить значною, що підтверджує закон Енгеля, відповідно до якого зі зростанням величини доходів частка витрат на товари першої необхідності зменшується $i$ навпаки. Доведено, щзо основною причиною нераціональної структури споживних витрат є високий рівень бідності серед громадян України.

У прочесі дослідження зроблено висновок, щуо у вітчизняний споживчий кошик обов'язково потрібно закласти кошти на комунальні послуги, оздоровлення тощз. У изьому випадку він зможе забезпечити не лише мінімальні потреби громадян Украӥни, а й сприятиме гідному рівню їхнього життя.

Ключові слова: витрати, продовольча безпека, заробітна плата, продукти, споживання, споживчий кошик, потреби.

Табл.: 2. Рис.: 8. Літ.: 29.

\title{
CURRENT STATE AND FEATURES OF FORMATION OF SOCIAL STANDARDS IN UKRAINE
}

BEREZIUK Sergiy, Candidate of Economic Sciences, Associate Professor of the Department of Administrative Management and Alternative Energy Sources, (Vinnytsia) 
The article considers the essence of economic category "food safety», identifies and characterizes its components, assesses the state of food safety in Ukraine and identifies the main factors influencing its state.

The norms of Ukrainian consumer basket in the food part and the actual consumption of food products are considered and it is established that they do not correspond to the scientifically substantiated recommendations of complete nutrition of the Ministry of Health of Ukraine. The analysis of the average annual consumption of basic foodstuffs shows that during 2000-2020 Ukrainians began to consume more food products, so in general they began to eat better, but their diet is suboptimal. It was found that when determining the product part of the domestic consumer basket, a method used was the one that was developed more than 30 years ago and does not take into account existing new and modern product groups, and, accordingly, needs to be improved taking into account world best practices.

It is established that the cost of the consumer basket is determined by the subsistence level, it is also the basis for determining the amount of pensions and the minimum wage.

The level of poverty in Ukraine has been studied and it has been determined that low incomes of citizens do not allow them to eat properly, which has a corresponding effect on the, structure of food consumed. As a consequence, the share of food expenditures in the total expenditures of Ukrainian households is quite significant, which confirms Engel's law, according to which, with increasing income, the share of expenditures on basic necessities decreases and vice versa. It is proved that the main reason for the irrational structure of consumer spending is the high level of poverty among the citizens of Ukraine.

Doing the research, the conclusion was made, that it is necessary to put funds for utilities, rehabilitation etc. in the domestic consumer basket. In this case, it will be able to provide not only the minimum needs of the citizens of Ukraine, but also contribute to dignified level of life.

Key words: costs, food security, wages, products, consumption, consumer basket, needs.

Tabl.: 2. Fig.: 8. Ref.: 29.

\title{
СОВРЕМЕННОЕ СОСТОЯНИЕ И ОСОБЕННОСТИ ФОРМИРОВАНИЯ СОЦИАЛЬНЫХ СТАНДАРТОВ В УКРАИНЕ
}

\author{
БЕРЕЗЮК С.В., \\ кандидат экономических наук, доцент \\ кафедры административного менеджсмента \\ и альтернативных источников энергии, \\ Винницкий национальный аграрный университет
} (2. Винница)

В статье рассмотрена сущность экономической категории «продовольственная безопасность», определены и охарактеризованы её составляющие, осуществлена оценка состояния продовольственной безопасности Украины и установлены основные факторы, влияющие на неё.

Рассмотрень нормы потребительской корзины украинца в продуктовой части и фактическое потреблении продуктов питания, а также установлено, что они не соответствуют научно обоснованным рекомендациям полноценного питания Министерства здравоохранения Украины. Анализ среднегодового потребления основных продуктов питания свидетельствует о том, что в течение 2000-2020 г2. украинць начали потреблять больше продуктов питания, то есть стали питаться лучше, однако их рацион является неоптимальным. Выяснено, что при определении продуктовой части отечественной потребительской корзины используется методика, которая была 
разработана более 30 лет назад и которая не учитывает существуюших новых $u$ современных групп товаров, и, соответственно, требует совершенствования с учётом передового мирового опыта.

Установлено, что стоимость набора потребительской корзинь определяется прожиточным минимумом, он также лежит в основе определения размера пенсий $и$ минимальной заработной платьл.

Исследован уровень бедности в Украине и определено, что низкие доходы граждан не дают возможность им полноченно питаться, что соответствующим образом влияет на структуру потребляемых продуктов питания. Как следствие, доля расходов на продукты питания в совокупных расходах домохозяйств украинцев достаточно значительна, что подтверждает закон Энгеля: с ростом величины доходов доля расходов на товары первой необходимости уменьшается и наоборот. Доказано, что основной причиной нерациональной структуры потребительских расходов является высокий уровень бедности среди граждан Украинье.

В прочессе исследования сделан вывод, что в отечественную потребительскую корзину обязательно нужно заложить средства на коммунальные услуги, оздоровление и тому подобное. В этом случае она сможет обеспечить не только минимальные потребности граждан Украины, но и будет способствовать достойному уровню их жизни.

Ключевые слова: расходы, продовольственная безопасность, заработная плата, продукты, потребление, потребительская корзина, потребности.

Табл.: 2. Рис.: 8. Лит.: 29.

Постановка проблеми. Досягнення високого рівня показників розвитку держави передбачає, насамперед, раціональне використання потенціалу ії населення. Задоволення фізіологічних потреб людей, зокрема, відповідне харчування - основна передумова їх розвитку й ефективної праці. Забезпечення населення безпечними й доступними продуктами харчування - це прямий обов'язок держави перед громадянами, який реалізується через формування соціальних стандартів. Варто зауважити, що існуючі соціальні стандарти, які затверджені Урядом, є застарілими та не відповідають сучасним потребам громадян. Сьогодні рівень продовольчої безпеки в Україні можна охарактеризувати як незадовільний, що вимагає подолання проблем неплатоспроможності й відповідного забезпечення значної частини населення базовими продуктами харчування.

Однією із причин кризового стану продовольчої безпеки України є той факт, що наш експорт має переважно сировинний характер. На думку Кубай О., Україна має чітко визначити параметри продовольчої безпеки, і на цій основі, розробити стратегію та напрями розвитку агропромислового комплексу з урахуванням раціонального використання його потенціалу й посилення експортної орієнтації [13, с. 63]. Фурман I. і Токарчук Д. вважають, що пошук найбільш вигідних стратегій забезпечення продовольчої i енергетичної безпеки 3 використанням сільськогосподарської сировини $\epsilon$ важливим завданням для будь-якої країни [26, с. 93]. Отже, питання забезпечення продовольчої безпеки й підвищення соціальних стандартів для України нині є надзвичайно гострим, що потребує пошуку варіантів вирішення проблем у цій сфері $[9$, с. 3].

Аналіз останніх досліджень і публікацій. Дослідженню питань продовольчої безпеки та соціальних стандартів України свої праці присвятили 


\section{$\mathbf{E \Phi M}$}

http://efm.vsau.org/

такі науковці: Калетнік Г. [9; 10], Токарчук Д. [26], Фурман I. [26], Кубай О. [13], Ротчук I. [21], Салій Н. [22], Щербатюк М. [28] та багато інших. Проте, ця проблематика $\epsilon$ досить багатогранною, що потребує подальших досліджень для обгрунтування основних напрямів ії розв'язання.

Формування цілей статті. Метою наукового дослідження $\epsilon$ аналіз особливостей формування соціальних стандартів в Україні та їхнього впливу на стан продовольчої безпеки, обгрунтування пропозицій щодо підвищення купівельної спроможності громадян задля подолання наявних проблем у забезпеченні продовольчої безпеки.

Виклад основного матеріалу дослідження. Одним із перших науковців, який вважав, що в основі розвитку особистості є фізіологічні потреби, був А. Маслоу. У 1943 році, досліджуючи фактори, які впливають на поведінку людини, науковець розмістив потреби людини у певній послідовності, що нагадують піраміду ієрархії. В основі цієї ієрархії лежать потреби «нижчого рівня» - фізіологічні (їжа, вода, житло), тоді як на вершині - розташовані потреби «вищого рівня», які можна окреслити такими категоріями: розвиток, визнання, самовираження (рис. 1) [3, с. 370].

\begin{tabular}{|l|}
\hline потреби самовираження \\
потреби у повазі \\
соціальні потреби \\
потреби у безпеці \\
фізіологічні потреби \\
\hline
\end{tabular}

Джерело: [3, с.370]

Рис. 1. Піраміда потреб людини за А. Маслоу

Варто зазначити, що тоді, коли потреби найнижчого рівня задоволені цілком, то людина починає приділяти увагу потребам наступного рівня, чим задовольняе їх.

На нашу думку, незважаючи на те, що ця піраміда має лише п'ять рівнів, вона фактично $\epsilon$ нескінченною, оскільки індивідуальні потреби мають невизначений характер і залежать від розвитку особистості та можуть постійно змінюватися, тоді як фізіологічні потреби є постійними та становлять основу життєдіяльності людини.

На державному рівні здатність громадянина забезпечити себе необхідною кількістю продуктів харчування трактується як забезпечення продовольчою безпекою. Відповідно до Закону України «Про державну підтримку сільського господарства України», продовольча безпека - захищеність життєвих інтересів людини, яка виражається у гарантуванні державою безперешкодного економічного доступу людини до продуктів харчування для підтримання іiі звичайної життєдіяльності [17]. У наказі Міністерства економічного розвитку й торгівлі України від 29.10.2013 р. № 1277 «Про затвердження Методичних рекомендацій щодо розрахунку рівня економічної безпеки України» сутність продовольчої безпеки трактується як стан виробництва продуктів харчування у 
країні, що здатний повною мірою забезпечити потреби кожного члена суспільства у продовольстві належної якості, за умови його збалансованості й доступності для кожного члена суспільства» [18]. Отже, незважаючи на певну різницю у трактуванні сутності поняття продовольча безпека, спільним у визначеннях $є$ доступність для людини продуктів харчування.

Продовольча безпека країни $є$ невід'ємною складовою безпеки: економічної, національної та елементом міжнародної продовольчої безпеки загалом, на яку впливають багато факторів [8, с. 4].

На думку Березіна О., продовольча безпека - це стабільний у часі й просторі процес безперебійного забезпечення всього населення країни різноманітними якісними продуктами харчування в обсягах, необхідних для здорового способу життя [4, с. 54].

Правильне харчування, 3 урахуванням умов життя, праці, побуту забезпечує сталість внутрішнього середовища організму людини, гармонійний розвиток, високу працездатність. Раціональне харчування - це точно розраховане забезпечення їжею, яке, насамперед, передбачає відповідність харчування фізіологічним потребам й енерговитратам людського організму [22].

Аналіз середньорічного споживання основних продуктів харчування в Україні за 2000-2020 рр. свідчить про те, що українці, за основними групами, загалом, почали харчуватися краще. Зокрема, на 1 особу у 2020 році порівняно 32000 роком збільшилися середньорічні обсяги споживання: м'яса та м'ясопродуктів - на 22,8 кг (більшою мірою - за рахунок м'яса птиці, частка якого за досліджуваний період в загальному споживанні м'яса усіх видів у середньому становила $37,4 \%$ ), молока та молокопродуктів - на 2,4 кг, риби та морепродуктів на 1,2 кг, яєць - на 5 шт., фруктів, ягід та винограду - на 20,4 кг. Проте, спостерігаємо зменшення споживання овочів та баштанних культур на 15,6 кг, хлібобулочних виробів - на 13,2 кг, цукру - на 3,6 кг на одну особу. Середньорічне споживання основних продуктів харчування однією особою в Україні протягом 2000-2020 років наведено у табл. 1.

Таблиия 1

Динаміка споживання продуктів харчування в домогосподарствах України в середньому за рік у розрахунку на одну особу, кг

\begin{tabular}{|l|c|c|c|c|c|c|}
\hline \multirow{2}{*}{\multicolumn{1}{|c|}{ Продукти харчування }} & \multicolumn{5}{|c|}{ Роки } & 2020 р. до \\
\cline { 2 - 6 } & 2000 & 2005 & 2010 & 2015 & 2020 & 2000 р., \pm \\
\hline Хлібопродукти & 109,2 & 123,6 & 111,6 & 102,0 & 96,0 & $-13,2$ \\
\hline М'ясо та м'ясні продукти, & 39,6 & 52,8 & 61,2 & 55,2 & 62,4 & 22,8 \\
\hline зокрема: - м'ясо птиці & 15,0 & 13,9 & 23,2 & 24,2 & 25,6 & 11,7 \\
\hline \multicolumn{1}{|c|}{ - свинина } & 13,4 & 11,7 & 18,0 & 18,1 & 19,5 & 7,8 \\
\hline \multicolumn{1}{|c|}{ - яловичина } & 10,3 & 12,6 & 9,8 & 8,2 & 7,9 & $-4,7$ \\
\hline Молоко, молокопродукти & 224,4 & 260,4 & 230,4 & 237,6 & 226,8 & 2,4 \\
\hline Риба, морепродукти & 15,6 & 21,6 & 21,6 & 14,4 & 16,8 & 1,2 \\
\hline Картопля & 122,4 & 115,2 & 92,4 & 79,2 & 72,0 & $-50,4$ \\
\hline Яйця, шт. & 228 & 252 & 240 & 228 & 233 & 5 \\
\hline Олія рослинна всіх видів & 18,0 & 22,8 & 21,6 & 19,2 & 16,8 & $-1,2$ \\
\hline Овочі та баштанні культури & 120,0 & 109,2 & 114,0 & 105,6 & 104,4 & $-15,6$ \\
\hline Фрукти, ягоди, виноград & 24,0 & 37,2 & 44,4 & 37,2 & 44,4 & 20,4 \\
\hline Цукор & 32,4 & 43,2 & 36,0 & 33,6 & 28,8 & $-3,6$ \\
\hline
\end{tabular}

Джерело: сформовано автором на основі даних [6; 23; 24] 
Найбільше українці вживають такі продукти, як: яйця, м'ясо, овочі й фрукти, що свідчить про зміну структури раціону харчування. Не беручи до уваги зростання обсягів спожитих продуктів, структура раціону споживання залишається незбалансованою, про що свідчить порівняння харчування щодо споживчого кошика пересічного українця 3 рекомендаційними нормами, розробленими Українським науково-дослідним інститутом гігієни й харчування (далі - УНДІ) Міністерства охорони здоров’я (табл. 2).

Таблиия 2

\section{Порівняння продовольчого споживчого кошика у 2020 р. 3 нормами}

\section{споживання в Україні, кг}

\begin{tabular}{|c|c|c|c|c|c|}
\hline \multirow[t]{2}{*}{ Продукти харчування } & \multicolumn{2}{|c|}{$\begin{array}{c}\text { Норми споживання за } \\
\text { рекомендацією УНДІ } \\
\text { Міністерства охорони здоров’я, } \\
\text { кг/рік }\end{array}$} & \multirow{2}{*}{$\begin{array}{c}\text { Норми } \\
\text { споживання за } \\
\text { Постановою } \\
\text { № } 780 \text { Кабінету } \\
\text { Міністрів України } \\
\text { від } 11.10 .2016 \text { р., } \\
\text { кг/рік }\end{array}$} & \multirow{2}{*}{$\begin{array}{c}\text { Фактичне } \\
\text { споживання } \\
\text { у } 2020 \text { році, } \\
\text { кг/рік }\end{array}$} & \multirow{2}{*}{$\begin{array}{c}\text { Відхилення } \\
\text { фактичного } \\
\text { споживання у } \\
2020 \text { р. від } \\
\text { раціональної } \\
\text { норми, \% }\end{array}$} \\
\hline & мінімальна & раціональна & & & \\
\hline Хлібопродукти & 94 & 101 & 101 & 96,0 & $-5,0$ \\
\hline М'ясо та м'ясні продукти & 52 & 80 & 53 & 62,4 & $-22,0$ \\
\hline Молоко, молокопродукти & 341 & 380 & 143,5 & 226,8 & $-40,3$ \\
\hline Риба, морепродукти & 12 & 20 & 13 & 16,8 & $-16,0$ \\
\hline Картопля & 96 & 124 & 95 & 72,0 & $-41,9$ \\
\hline ЯйцЯ, шт. & 231 & 290 & 220 & 233,0 & $-19,7$ \\
\hline Олія рослинна всіх видів & 8 & 13 & 7,1 & 16,8 & 29,2 \\
\hline $\begin{array}{l}\text { Овочі та баштанні } \\
\text { культури }\end{array}$ & 105 & 161 & 110 & 104,4 & $-35,2$ \\
\hline Фрукти, ягоди, виноград & 68 & 90 & 64 & 44,4 & $-50,7$ \\
\hline Цукор & 32 & 38 & 24 & 28,8 & $-24,2$ \\
\hline
\end{tabular}

Джерело: сформовано автором на основі [6; 7; 19]

Отже, фактичне споживання продуктів харчування та чинний продуктовий споживчий кошик не відповідають рекомендованим нормам Міністерства охорони здоров’я України (рис. 2).

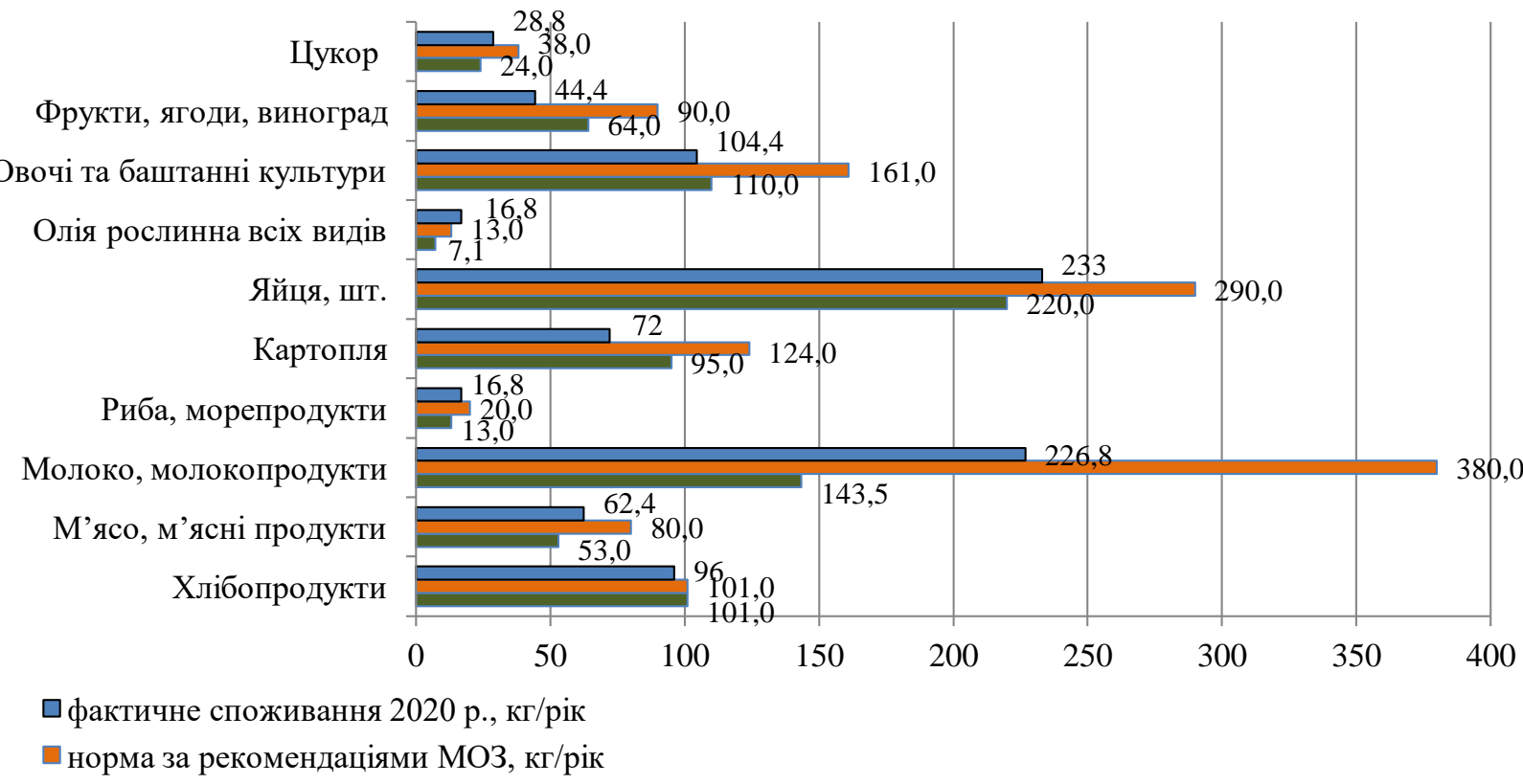

\footnotetext{
Рис. 2. Набір продуктів харчування у 2020 році та його відповідність рекомендованим нормам в Україні, кг/рік

Джерело: сформовано автором на основі [6; 7; 19]
} 
Овочі, баштанні культури й картоплю українці споживають понад норму, тоді як інших видів продуктів вживають менше рекомендаційних норм. Експерти стверджують, що обсяг споживчого кошика потрібно збільшити на 20-25\%, адже передбачені норми значно занижені й не відповідають реальним потребам людини. Наприклад, споживчий кошик у розрахунку на календарний рік містить 53 кг м'яса, а реальна потреба - 83 кг; споживання молока - 143 кг при фізіологічній нормі - 380 кг. Варто зазначити, що в основі вітчизняного споживчого кошика лежить методика Ленінградського інституту гігієни харчування (1990 р.), яка, відповідно, потребує змін і перерахунку 3 урахуванням існуючих нових і сучасних груп товарів [21].

Сьогодні в Україні постала проблема відповідності набору й обсягу товарів мінімального споживчого кошику медичним стандартам. Отже, набори продуктів харчування, непродовольчих товарів і послуг, що складають теперішній споживчий кошик, взагалі можна вважати нелегітимними [6].

Існуючі нормативи харчування та фактичний стан продуктового кошику $\epsilon$ порушенням статті 48 Конституції, у якій зазначено, що «...кожен має право на достатній життєвий рівень для себе і своєї сім'ї, що включає достатнє харчування, одяг, житло» [12]. Сукупність вищезазначених факторів становить загрозу продовольчій безпеці держави та, відповідно, знижує рейтинг країни у світовій спільноті.

Ще одним показником продовольчої безпеки країни, який вказує на достовірну доступність продуктів харчування, $\epsilon$ глобальний індекс продовольчої безпеки - оцінка продовольчої безпеки у країнах світу за допомогою індексу, який розраховується з 2012 року й містить чотири складові: економічна та фізична доступність продовольства, якість та безпечність, природні ресурси та стійкість [2].

Україна станом на 2020 рік займає 54 місце серед країн світу у рейтингу продовольчої безпеки, що загалом є низьким показником (рис. 3).

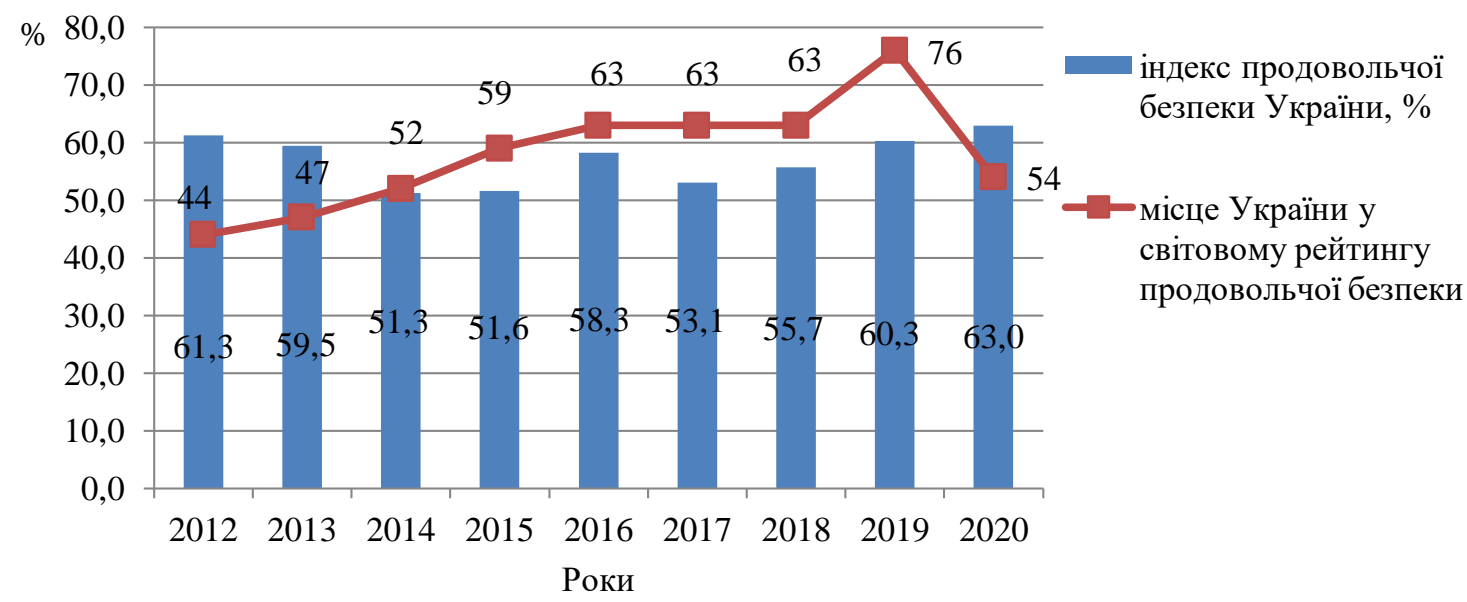

Рис. 3. Місце України у світовому рейтингу й індекс їі продовольчої безпеки у 2012-2020 pp.

Джерело: [2]

Лідерами у світовому рейтингу продовольчої безпеки є Фінляндія та Ірландія, які займають 1 та 2 місця відповідно [2]. За підрахунками фахівців 
міжнародної сільськогосподарської компанії Corteva Agriscience, за наявності технологічних рішень, залученні інвестицій в агропромисловий комплекс й інтеграції в міжнародні ланцюги постачання, Україна здатна прогодувати 500 млн населення [25].

Основними сильними сторонами, які визначають індекс продовольчої безпеки України, є: безпека харчових продуктів; низька частка населення держави за межею бідності; мінімальні витрати на харчування; низький рівень втрат продовольства. Найбільший негативний вплив справляють такі фактори, як: високий рівень корупції, дорогі кредити, політична нестабільність [2]. Основні складові індексу продовольчої безпеки України у 2020 році відображено на рис. 4.

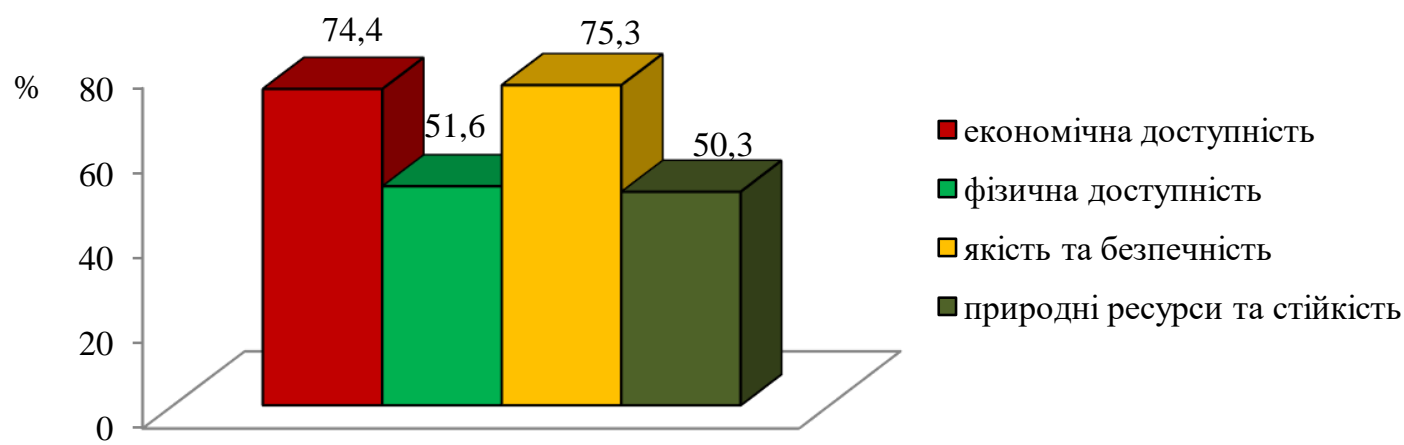

Рис. 4. Основні складові індексу продовольчої безпеки України за 2020 рік, \%

Джерело: [2]

На нашу думку, наявний рівень економічної доступності продуктів харчування в Україні $є$ сумнівним, оскільки для його розрахунку використовують усереднені показники по державі загалом за певний період. Про це свідчить і той факт, що рівень бідності в Україні у 2020 році, за даними аналітичного порталу «Слово і діло», становив 43,6\%, тоді як, відповідно до аналітичних досліджень Державної служби статистики України, він становить $1,6 \%$ (рис. 5 ).

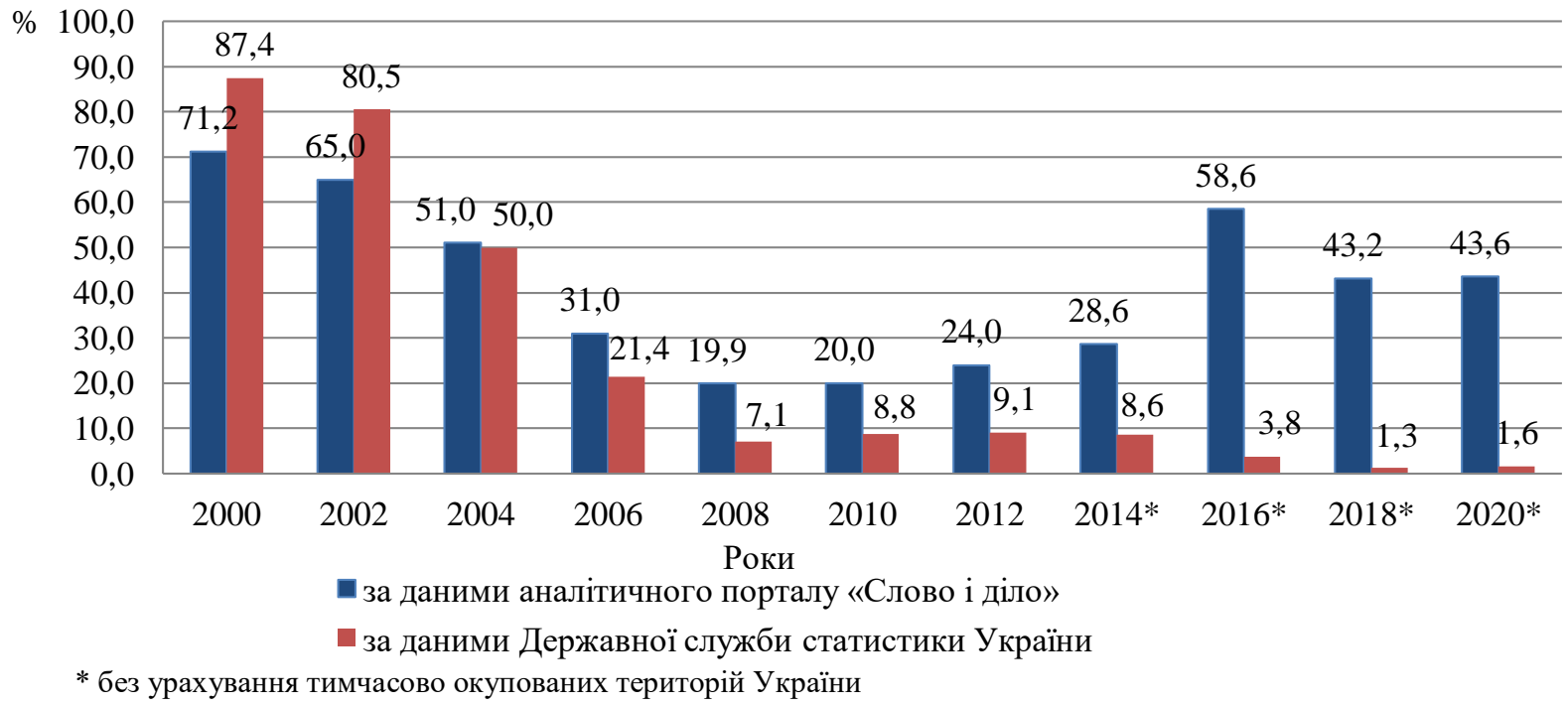

Рис. 5. Рівень бідності в Україні 2000-2020 рр., \%

Джерело: сформовано автором на основі [6; 29] 
Показник бідності населення розраховується як різниця між доходом людини або сім'ї та рівнем прожиткового мінімуму, який визначений державою. Світовий банк сьогодні дає визначення абсолютної бідності, як такої, за якої людина живе менш, ніж на 1,25 \$ (приблизно 0,9 євро) в день [14]. За даними аналітичного порталу «Слово і діло», в Україні найвищий рівень бідності був зафіксований у 2000 році - 71,2\%, у наступні роки цей показник знижувався, а у 2008 році досяг мінімального значення - 19,9\%. За період 20082013 pp. рівень бідності мав змінну динаміку, а починаючи 32014 року, внаслідок окупації Криму й початку бойових дій на сході, - почав зростати. У результаті економічної кризи, за межею бідності можуть опинитися 6 млн громадян. Найбільш вразливими категоріями населення є багатодітні сім'ї, одинокі батьки 3 дітьми, родини 3 дітьми до трьох років й одинокі люди старші 65 років [29].

Варто зазначити, що питома вага продуктів харчування та безалкогольних напоїв у загальній структурі сукупних витрат домогосподарств за досліджуваний період (2000-2020 рр.) становить, у середньому, 52,81\% та в динаміці зменшується, хоча в абсолютному вимірі витрати на їжу збільшуються [6] (рис. 6). Наші дослідження підтверджують закон Енгеля, за яким під час зростання доходів зменшується частка витрат на харчування. В економічно розвинених державах цей показник становить від $10 \%$ до 15\%, тобто чим більш розвинута країна, тим меншу частку витрат ії населення витрачає на продукти харчування [11]. Найменше на продукти харчування витрачають громадяни таких країн: США, Сінгапур, Велика Британія, Ірландія, Канада, Швейцарія, Австралія та Австрія, де витрати становлять менше 10\%. Україна посідає 93 місце цього рейтингу, та випереджає Уганду (частка витрат на харчування - 44,2\%), Казахстан (44,9\%), Анголу $(48,6 \%)$, Бангладеш $(53,5 \%)$ та Нігерію (59,0\%) [27].

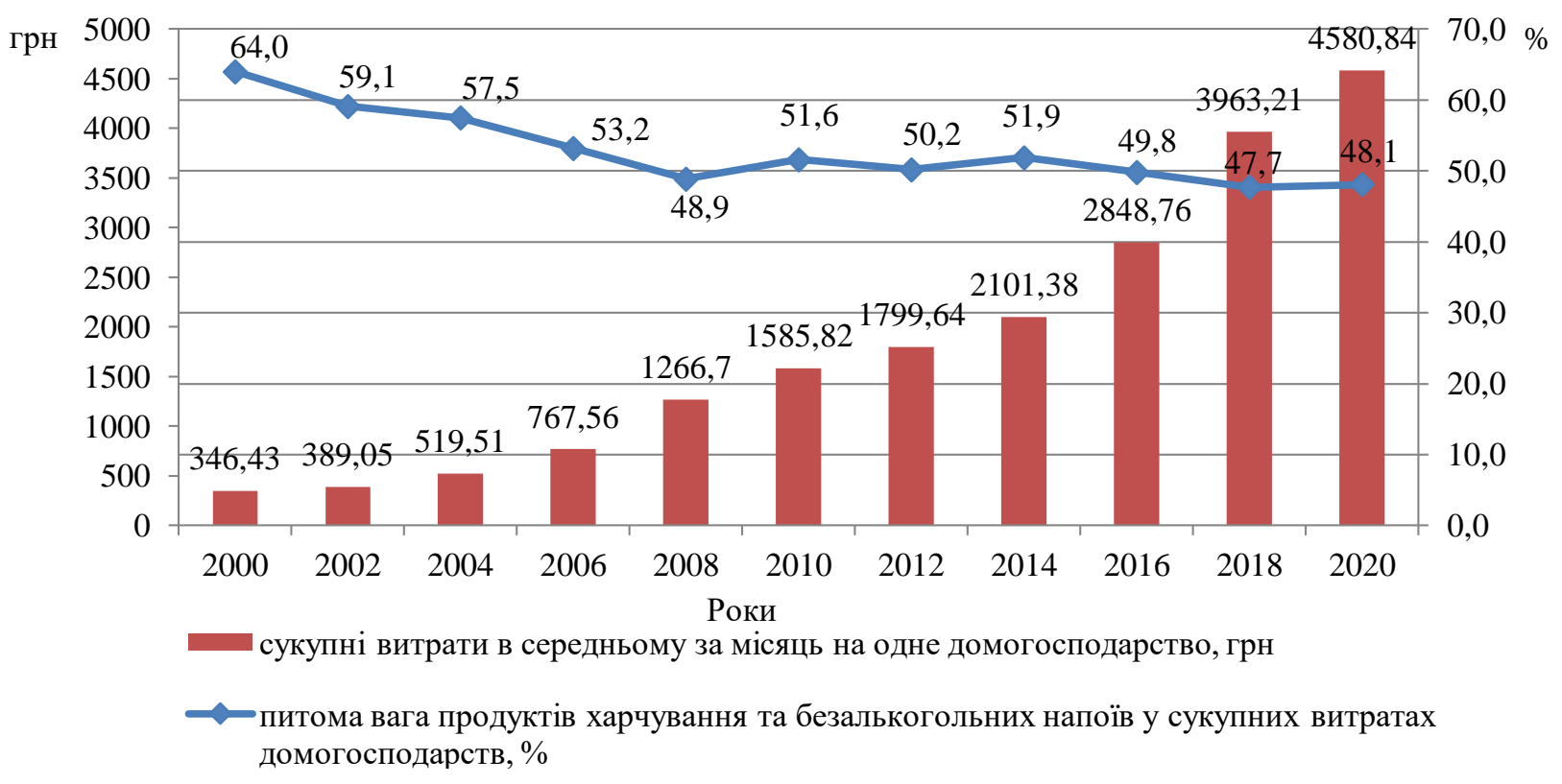

Рис. 6. Частка витрат на продукти харчування у сукупних витратах домогосподарств України, 2000-2020 рр., \% 
Отже, незважаючи на те, що в Україні формально умова забезпечення продовольчої безпеки виконується, продовольчі витрати становлять значну частку витрат населення, що свідчить про низький рівень життя та загрозу продовольчій безпеці. Низька купівельна спроможність населення $є$ найбільш важливим чинником низького продовольчого забезпечення українців [11].

Значний вплив на купівельну спроможність населення України має прожитковий мінімум, який досить часто $є$ основою існування пересічних українців. Прожитковий мінімум - вартісна величина достатнього для забезпечення звичайного функціонування організму людини, збереження його здоров'я набору продуктів харчування, а також мінімального набору непродовольчих товарів i мінімального набору послуг, необхідних для задоволення основних соціальних і культурних потреб особистості [20]. Затвердженню прожиткового мінімуму передує проведення відповідної науково-громадської експертизи щодо набору продуктів харчування та непродовольчих товарів, після чого він затверджується Верховною Радою України в законі про Державний бюджет України на відповідний рік.

У величину вітчизняного прожиткового мінімуму не закладено багато необхідних витрат, які постійно повинні нести пересічні українці, а саме: ремонт чи купівля житла, його найм; оздоровлення; утримання дітей у дошкільних навчальних закладах; платні медичні послуги тощо. У прожитковому мінімумі також не враховано постійне зростання вартості комунальних послуг. Варто зазначити, що під час розрахунку загального показника в Україні не беруться до уваги регіональні відмінності цін на продовольчі й непродовольчі товари. На думку експертів, якби споживчий кошик було наповнено реальним змістом, видаткову частину бюджету необхідно було б збільшити у три рази [28].

Зазвичай, вартість набору споживчого кошика українця визначається прожитковим мінімумом, що також впливає на розміри пенсій та мінімальної заробітної плати. Динаміка прожиткового мінімуму й мінімальної заробітної плати в Україні наведено на рис. 7.

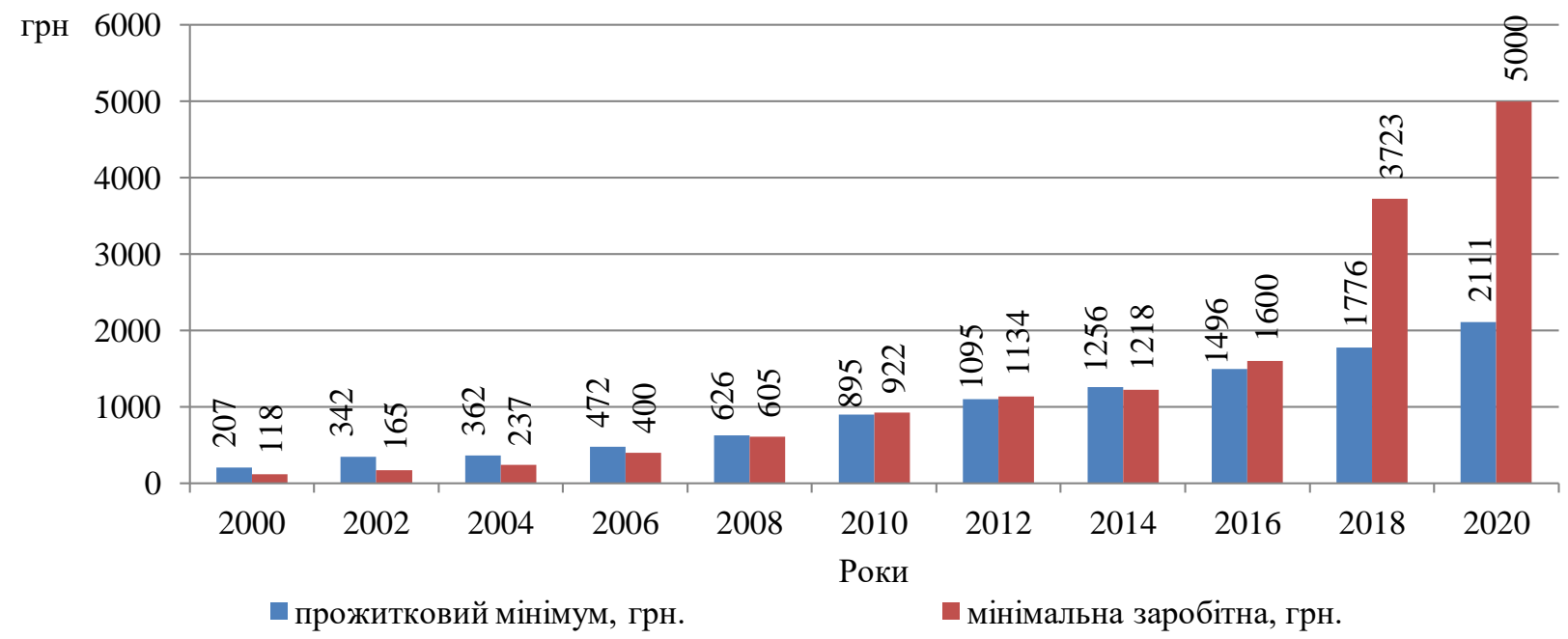

Рис. 7. Динаміка прожиткового мінімуму та мінімальної заробітної плати в Україні, 2000-2021 рр., грн

Джерело: сформовано автором на основі [15; 20] 


\section{EФM}

http://efm.vsau.org/

За розрахунками Федерації профспілок України, розмір прожиткового мінімуму, який $є$ відправною точкою у формуванні мінімальних соціальних стандартів, повинен бути втричі більшим.

Загалом, аналізуючи динаміку споживчих витрат домогосподарств i соціальних стандартів в Україні, варто зауважити, що витрати домогосподарств суттєво перевищують їхні доходи (рис. 8).

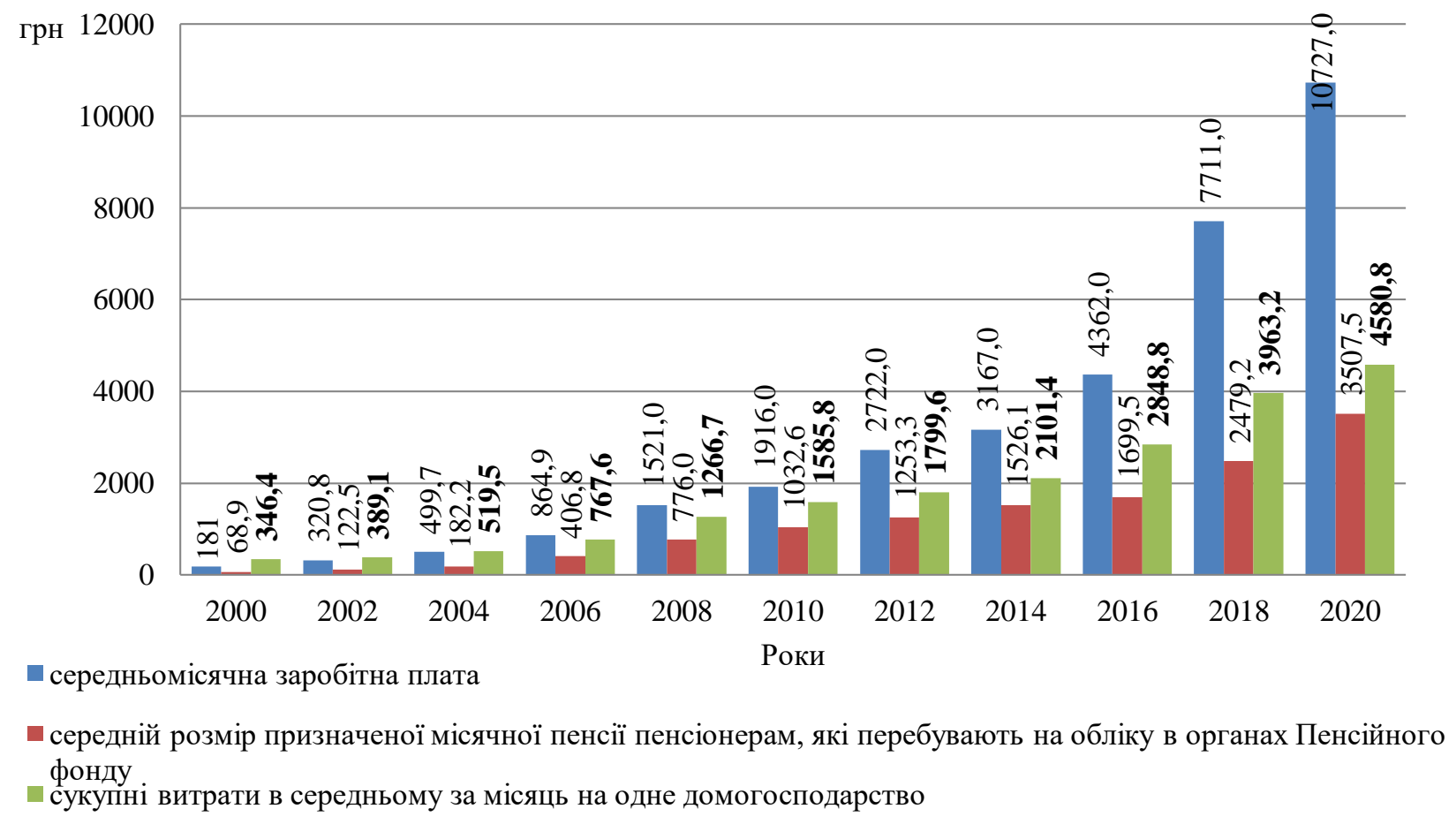

Рис. 8. Динаміка споживчих витрат домогосподарств та соціальних стандартів в Україні 2000-2020 рр., грн

Джерело: сформовано автором на основі [1; 6]

У середньому українець витрачає 102-127\% від заробітної плати [16]. Вищезазначене свідчить про те, що вітчизняні соціальні стандарти не відповідають вимогам сьогодення, а громадяни приховують реальні доходи для уникнення податків й отримання певних пільг від держави.

Висновки. Забезпечення продовольчої безпеки країни $\epsilon$ одним iз основних стратегічних завдань держави й невід'ємною складовою національної безпеки.

На жаль, продуктовий споживчий кошик в Україні сьогодні не відповідає раціональним нормам споживання. Проведений аналіз існуючих норм підтвердив необхідність їх модернізації, оскільки вони є застарілими й не містять цілої низки продуктів харчування, які рекомендуються міжнародними організаціями.

Для покращення існуючого стану продовольчої безпеки в Україні та оптимізації норм споживання продуктів харчування пересічним громадянином $\mathrm{i}$ наближення їх до науково-обгрунтованих рекомендацій МO3, варто здійснити комплекс заходів на державному рівні. Насамперед, це передбачає індексацію доходів громадян із урахуванням інфляційних процесів.

Проведений аналіз свідчить про те, що наявні соціальні стандарти не 
відповідають реаліям, адже місячні витрати громадян іноді удвічі перевищують їхні доходи. Це підтверджує те, що мінімальні соціальні стандарти, які є базою для обрахування заробітної плати й пенсій, потребують суттєвого збільшення як мінімум удвічі. Загалом, варто зазначити, що соціальні стандарти повинні забезпечувати гідний рівень життя населення країни й сприяти його всебічному розвитку, а не забезпечувати лише найважливіші потреби людини фізіологічні.

Також потребує перегляду та значного розширення непродовольча складова споживчого кошика - сукупність послуг і непродовольчих товарів, які необхідні громадянам для задоволення власних потреб (наприклад, на оплату комунальних послуг, оздоровлення та ін.). Отже, існуючий споживчий кошик це цілковитий мінімалізм, його потрібно оптимізувати, беручи за основу передові світові практики, але, водночас, варто враховувати стан вітчизняної економіки.

\section{Список використаних джерел}

1. 29-років незалежності: зміни в Україні в цифрах i графіках. I URL: https://ru.slovoidilo.ua/2020/08/21/infografika/obshhestvo/29-let-nezavisimostiizmeneniya-ukraine-cifrax-i-grafikax (дата звернення: 02.08.2021).

2. Global Food Security Index. URL: https://foodsecurityindex.eiu.com/Index (дата звернення: 04.09.2021).

3. Maslow A.H. A theory of human motivation. Psychological Review. 1943. № 50 (4). P. 370-396.

4. Березін О.В. Проблеми формування продовольчого ринку України: монографія. Київ: Вища школа, 2002. $211 \mathrm{c}$.

5. Березюк С.В., Колесов О.С. Особливості формування соціальних стандартів у контексті споживчих витрат в Україні. Бізнес Інформ. 2016. № 2. C. 241-247.

6. Державна служба статистики України. Веб-сайт. URL: http://www.ukrstat.gov.ua. (дата звернення: 01.09.2021).

7. Звіт про стан продовольчої безпеки України у 2013 році. URL: https://www.me.gov.ua/Documents/Download?id=c06d7392-f237-4e56-a2dd9e511a3e53c4 (дата звернення: 13.09.2021).

8. Іртищева І.О., Рогатіна Л.П., Ільницька О.С. Продовольча безпека важливий елемент економічної та національної безпеки. Агросвіт. 2020. № 22. C. 3-8. DOI: 10.32702/2306-6792.2020.22.3

9. Калетнік Г.М., Гончарук I.В., Смчик Т.В., Лутковська С.М. Аграрна політика та земельні відносини: підручник. Вінниця: ВНАУ, 2020. $307 \mathrm{c}$.

10. Калетнік Г.М., Дармограй О.В. Методичні підходи до оцінки та аналіз індикаторів продовольчої безпеки України. Економіка, фінанси, менеджмент: актуальні питання науки і практики. 2016. № 6 (10). С. 7-20.

11. Клименко Н.А. Регіональні аспекти продовольчої безпеки України. Ефрективна економіка. 2020. № 7. DOI: 10.32702/2307-2105-2020.7.56. URL: http://www.economy.nayka.com.ua/?op=1\&z=8048 (дата звернення: 20.08.2021).

12. Конституція України від 28 червня 1996 р. № 254к/96-BP. URL: 
https://zakon.rada.gov.ua/laws/show/254\%D0\%BA/96-\%D0\%B2\%D1\%80\#Text (дата звернення: 04.04.2021).

13. Кубай О.Г., Коломієць Х.М. Аграрне виробництво в системі забезпечення продовольчої безпеки держави. Проблеми системного підходу в економіиі. 2017. № 5 (61). С. 63-69.

14. Майже половина українців на межі бідності: навіть із роботою не можуть забезпечити сім'ї. URL: https://thepage.ua/ua/news/riven-bidnosti-vukrayini-pidsumki-2020-roku-prognoz-2021 (дата звернення: 02.08.2021).

15. Мінімальна зарплата в Україні. URL: https://index.minfin.com.ua/ ua/labour/salary/min/ (дата звернення: 18.09.2021).

16. Пігуляк Ю. Проблема прожиткового мінімуму, або чи скоро українці почнуть голодувати? URL: http://www.zunr.info/news/2014/08/09/65755-problema -prozhytkovogo-minimumu-abo-chy-skoro-ukrayinci-pochnut-goloduvaty.html (дата звернення: 01.09.2021).

17. Про державну підтримку сільського господарства України: Закон України від 24 червня 2004 р. № 1877-IV. URL: https://zakon.rada.gov.ua/ laws/show/1877-15\#Техt (дата звернення: 28.08.2021).

18. Про затвердження Методичних рекомендацій щодо розрахунку рівня економічної безпеки України: Наказ Міністерства економічного розвитку i торгівлі України від 29 жовтня 2013 № 1277. URL: https://zakon.rada.gov.ua/rada/show/v1277731-13\#Text (дата звернення: 16.08.2021).

19. Про затвердження наборів продуктів харчування, наборів непродовольчих товарів та наборів послуг для основних соціальних i демографічних груп населення: Постанова Кабінету Міністрів України від 11 жовтня 2016 р. № 780. URL: https://zakon.rada.gov.ua/laws/ show/780-2016$\% \mathrm{D} 0 \% \mathrm{BF}$ Техt (дата звернення: 02.09.2021).

20. Прожитковий мінімум в Україні 2021. URL: https://index.minfin.com.ua/ ua/labour/wagemin/ (дата звернення: 01.09.2021).

21. Ротчук I. Споживчий кошик українця - суцільний мінімалізм. URL: http://harchi.info/articles/spozhivchiy-koshik-ukrayincya-sucilniy-minimalizm (дата звернення: 02.08.2021).

22. Салій Н.C. Раціональне харчування в сучасних умовах. URL: http:// zdorov.com.ua/nutrition.html (дата звернення: 12.08.2021).

23. Споживання свинини в Україні збільшилося майже на 7\%. URL: https://infoindustria.com.ua/spozhivannya-svinini-v-ukrayini-zbilshilosya-na-7/ (дата звернення: 11.11.2021).

24. Споживання свинини у 2021-му зросло. URL: https://pigua.info/uk/post/ spozivanna-svinini-u-2021-mu-zroslo (дата звернення 01.12.2021).

25. Україна посіла 54 місце у Глобальному індексі продовольчої безпеки 2020 року. URL: https://agravery.com/uk/posts/show/ukraina-posila-54-misce-uglobalnomu-indeksi-prodovolcoi-bezpeki-2020-roku (дата звернення: 17.08.2021).

26. Фурман I.В., Токарчук Д.М. Продовольча безпека та економічні засади виробництва біопалива. Економічний аналіз. 2018. Т. 28. № 1. C. 92-98.

27. Частка витрат на харчування в Україні залишається однією 3 
найвищих у світі. URL: https://infoindustria.com.ua/chastka-vitrat-naharchuvannya-v-ukra\%D1\%97ni-zalisha\%D1\%94tsya-odni\%D1\%94yu-z-najvishhihu-sviti/ (дата звернення: 04.08.2021).

28. Щербатюк M. Секрети прожиткового мінімумy. URL: http://www.ilaw.kiev.ua/секрети-прожиткового-мінімуму/ (дата звернення: 11.08.2021).

29. Як змінювався рівень бідності в Україні за останні 20 років. URL: https://www.slovoidilo.ua/2021/02/16/infografika/suspilstvo/yak-zminyuvavsyariven-bidnosti-ukrayini-ostanni-20-rokiv (дата звернення: 16.08.2021).

\section{References}

1. 29 rokiv nezalezhnosti: zminy $\mathrm{v}$ Ukraini $\mathrm{v}$ tsyfrakh i hrafikakh [29 years of independence: changes in Ukraine in numbers and graphs]. ru.slovoidilo.ua. Retrieved from: https://ru.slovoidilo.ua/2020/08/21/infografika/obshhestvo/29-letnezavisimosti-izmeneniya-ukraine-cifrax-i-grafikax [in Ukrainian].

2. Global Food Security Index. foodsecurityindex.eiu.com. Retrieved from: https://foodsecurityindex.eiu.com/Index [in English].

3. Maslow, A.H. (1943). A theory of human motivation. Psychological Review, خे 50 (4), 370-396 [in English].

4. Berezin, O.V. (2002). Problemy formuvannia prodovolchoho rynku Ukrainy [Problems of formation of the food market of Ukraine]. Kyiv: Vyshcha shkola [in Ukrainian].

5. Berezyuk, S.V., \& Kolesov, O.S. (2016). Osoblyvosti formuvannia sotsialnykh standartiv u konteksti spozhyvchykh vytrat v Ukraini [Features of the formation of social standards in the context of consumer spending in Ukraine]. Biznes Inform - Business Inform, 2, 241-247 [in Ukrainian].

6. Derzhavna sluzhba statystyky Ukrayiny [State Statistics Service of Ukraine]. ukrstat.gov.ua. Retrieved from: http://www.ukrstat.gov.ua [in Ukrainian].

7. Zvit pro stan prodovolchoi bezpeky Ukrainy u 2013 rotsi [Report on the state of food security of Ukraine in 2013]. me.gov.ua. Retrieved from: https://www.me.gov.ua/Documents/Download?id=c06d7392-f237-4e56-a2dd-9e511a 3e 53c4 [in Ukrainian].

8. Irtyshcheva, I.O., Rohatina, L.P., \& Ilnytska, O.S. (2020). Prodovolcha bezpeka - vazhlyvyi element ekonomichnoi ta natsionalnoi bezpeky [Food security is an important element of economic and national security]. Ahrosvit-Agroworld, 22, 3-8. DOI: 10.32702/2306-6792.2020.22.3 [in Ukrainian].

9. Kaletnik, G.M., Honcharuk, I.V., Yemchyk, T.V., \& Lutkovska, S.M. (2020). Ahrarna polityka ta zemelni vidnosyny [Agrarian policy and land relations]. Vinnytsya: VNAU [in Ukrainian].

10. Kaletnik, G.M., \& Darmohray, O.V. (2016). Metodychni pidkhody do otsinky ta analiz indykatoriv prodovolchoi bezpeky Ukrainy [Methodical approaches to the assessment and analysis of food security indicators in Ukraine]. Ekonomika, finansy, menedzhment: aktualni pytannia nauky $i$ praktyky - Economy, finances, management: topical issues of science and practical activity, 6 (10), 7-20 [in Ukrainian].

11. Klymenko, N.A. (2020). Rehionalni aspekty prodovolchoi bezpeky Ukrainy [Regional aspects of food security of Ukraine]. Efektyvna ekonomika - 
Efficent economy. 7. Retrieved from: http://www.economy.nayka.com.ua/ ?op=1\&z=8048. DOI: 10.32702/2307-2105-2020.7.56 [in Ukrainian].

12. Konstytutsiia Ukrainy [Constitution of Ukraine]. (1996, June 28). zakon.rada.gov.ua. Retrieved from: https://zakon.rada.gov.ua/laws/show/254k/96vr\#Text [in Ukrainian].

13. Kubay, O.H., \& Kolomiyets, Kh.M. (2017). Ahrarne vyrobnytstvo v systemi zabezpechennia prodovolchoi bezpeky derzhavy [Agricultural production in the system of food security of the state]. Problemy systemnoho pidkhodu v ekonomitsi - Problems of system approach in economy, 5 (61), 63-69 [in Ukrainian].

14. Maizhe polovyna ukraintsiv na mezhi bidnosti: navit iz robotoiu ne mozhut zabezpechyty simyi [Almost half of Ukrainians are on the brink of poverty: even with work they cannot provide their families]. thepage.ua. Retrieved from: https://thepage.ua/ua/news/riven-bidnosti-v-ukrayini-pidsumki-2020-roku-prognoz2021 [in Ukrainian].

15. Minimalna zarplata $\mathrm{v}$ Ukraini [The minimum wage in Ukraine]. index.minfin.com.ua. Retrieved from: https://index.minfin.com.ua/ ua/labour/salary/min/ [in Ukrainian].

16. Pihulyak, Yu. (2014). Problema prozhytkovoho minimumu, abo chy skoro ukraintsi pochnut holoduvaty? [The problem of the subsistence level, or will Ukrainians soon start starving?]. www.zunr.info. Retrieved from: http://www.zunr.info/news/2014/08/09/65755-problema-prozhytkovogo-minimumuabo-chy-skoro-ukrayinci-pochnut-goloduvaty.html [in Ukrainian].

17. Pro derzhavnu pidtrymku silskoho hospodarstva Ukrainy: Zakon Ukrainy № 1877-IV [Law of Ukraine «On state support of agriculture of Ukraine» № 1877-IV]. (2004, June 24). zakon.rada.gov.ua. Retrieved from: https://zakon.rada.gov.ua/laws/show/1877-15\#Text [in Ukrainian].

18. Pro zatverdzhennia Metodychnykh rekomendatsii shchodo rozrakhunku rivnia ekonomichnoi bezpeky Ukrainy: Nakaz Ministerstva ekonomichnoho rozvytku i torhivli Ukrainy № 1277 [On approval of Methodical recommendations for calculating the level of economic security of Ukraine: Order of the Ministry of Economic Development and Trade of Ukraine № 1277]. (2013, October 29). zakon.rada.gov.ua. Retrieved from: https://zakon.rada.gov.ua/rada/show/v127773113\#Text [in Ukrainian].

19. Pro zatverdzhennia naboriv produktiv kharchuvannia, naboriv neprodovolchykh tovariv ta naboriv posluh dlia osnovnykh sotsialnykh i demohrafichnykh hrup naselennia: Postanova Kabinet Ministriv Ukrainy № 780 [On approval of sets of food products, sets of non-food products and sets of services for the main social and demographic groups of the population: Resolution of the Cabinet of Ministers of Ukraine № 780]. (2016, October 11). zakon.rada.gov.ua. Retrieved from: https://zakon.rada.gov.ua/laws/show/780-2016-\%D0\%BF\#Text [in Ukrainian].

20. Prozhytkovyi minimum v Ukraini 2021 [Subsistence level in Ukraine 2021]. index.minfin.com.ua. Retrieved from: https://index.minfin.com.ua/ ua/labour/wagemin/ [in Ukrainian].

21. Rotchuk, I. (2013). Spozhyvchyi koshyk ukraintsia - sutsilnyi minimalizm [The Ukrainian consumer basket is a complete minimalism]. harchi.info. Retrieved from: http://harchi.info/articles/spozhivchiy-koshik-ukrayincya-sucilniy-minimalizm 
[in Ukrainian].

22. Saliy, N.S. (2016). Ratsionalne kharchuvannia v suchasnykh umovakh [Rational nutrition in modern conditions]. zdorov.com.ua. Retrieved from: http://zdorov.com.ua/nutrition.html [in Ukrainian].

23. Spozhyvannia svynyny v Ukraini zbilshylosia maizhe na 7\% [Consumption of pork in Ukraine increased by almost 7\%]. infoindustria.com.ua. Retrieved from: https://infoindustria.com.ua/spozhivannya-svinini-v-ukrayini-zbilshilosya-na-7/ [in Ukrainian].

24. Spozhyvannia svynyny u 2021-mu zroslo [Consumption of pork in Ukraine increased]. pigua.info. Retrieved from: https://pigua.info/uk/post/ spozivanna-svininiu-2021-mu-zroslo [in Ukrainian].

25. Ukraina posila 54 mistse u Hlobalnomu indeksi prodovolchoi bezpeky 2020 roku [Ukraine ranked 54th in the 2020 Global Food Security Index]. agravery.com. Retrieved from: https://agravery.com/uk/posts/show/ukraina-posila54-misce-u-globalnomu-indeksi-prodovolcoi-bezpeki-2020-roku [in Ukrainian].

26. Furman, I.V., \& Tokarchuk, D.M. (2018). Prodovolcha bezpeka ta ekonomichni zasady vyrobnytstva biopalyva [Food security and economic principles of biofuel production]. Ekonomichnyi analiz - Economic analysis, 28 (1), 92-98 [in Ukrainian].

27. Chastka vytrat na kharchuvannia $v$ Ukraini zalyshaietsia odniieiu $\mathrm{Z}$ naivyshchykh u sviti [The share of food expenditures in Ukraine remains one of the highest in the world]. infoindustria.com.ua. Retrieved from: https://infoindustria.com.ua/chastka-vitrat-na-harchuvannya-v-ukra\%D1\%97ni-zalisha $\%$ D1\%94tsya-odni\%D1\%94yu-z-najvishhih-u-sviti/ [in Ukrainian].

28. Shcherbatyuk, M. (2016). Sekrety prozhytkovoho minimumu [Secrets of the subsistence level]. www.i-law.kiev.ua. Retrieved from: http://www.ilaw.kiev.ua/sekrety-prozhytkovoho-minimumu/ [in Ukrainian].

29. Yak zminiuvavsia riven bidnosti $v$ Ukraini za ostanni 20 rokiv [How the level of poverty in Ukraine has changed over the last 20 years]. www.slovoidilo.ua. Retrieved from: https://www.slovoidilo.ua/2021/02/16/ infografika/suspilstvo/yak-zminyuvavsya-riven-bidnosti-ukrayini-ostanni-20-rokiv [in Ukrainian].

\section{Відомості про авторів}

БЕРЕЗЮК Сергій Володимирович - кандидат економічних наук, доцент кафедри адміністративного менеджменту та альтернативних джерел енергії, Вінницький національний аграрний університет (21008, м. Вінниця, вул. Сонячна, 3, e-mail: sergejj.berezjuk@gmail.com).

BEREZIUK Sergiy - Candidate of Economic Sciences, Associate Professor of the Department of Administrative Management and Alternative Energy Sources, Vinnytsia National Agrarian University (21008, Vinnytsia, 3, Soniachna Str., e-mail: sergejj.berezjuk@gmail.com).

БЕРЕЗЮК Сергей Владимирович - кандидат экономических наук, доцент кафедры административного менеджмента и альтернативных источников энергии, Винницкий национальный аграрный университет (21008, г. Винница, ул. Солнечная, 3, e-mail: sergejj.berezjuk@gmail.com). 